\title{
The Structure and Dynamics of Macrozoobenthic Communities of the Bega River Water
}

\author{
Anca-Andreea MARIN ${ }^{1 *}$, Benoni LIXANDRU ${ }^{1}$, Milca PETROVICI ${ }^{2}$, Adrian SINITEAN ${ }^{2}$, Florica MORARIU ${ }^{1}$, \\ Dumitru POPESCU ${ }^{1}$
${ }^{1}$ Banat University of Agricultural Sciences and Veterinary Medicine "King Michael I of Romania" from Timisoara, Faculty of Animal Science and Biotechnology,
${ }^{2}$ West University of Timişoara, Faculty of Chemistry Biology and Geography, Department of Chemistry- Biology, Timişoara, Romania
*corresponding author, e-mail: marin.aandreea@yahoo.com

Bulletin UASVM series Agriculture 73(1)/2016

Print ISSN 1843-5246; Electronic ISSN 1843-5386

DOI 10.15835/buasvmcn-agr: 12010

\begin{abstract}
The benthic macro invertebrates are good indicators of localized conditions, as many of the benthic macro invertebrates have limited migration patterns or a sessile mode of life. Most species have a complex life cycle of one year or more. Sensitive life stages will respond quickly to stress; the overall community will respond more slowly. The structure and distribution of the different benthonic macro-invertebrates communities is considered to be one of the important indicators of the surface waters' quality. In November 2014, were collected 20 quantitative samples of benthic zones, in the Bega River in order to highlight the links between pollution degree and the saprobionte organisms community. The aim of this paper is to show the effects of human impact (Ghiroda village, potable water treatment station, sewage water treatment station of Timisoara, Sânmihaiu Roman village) on benthic community structure and dynamics of different ecosystems from Bega River water. After the laboratory work was carried out, it was identified ten groups of benthic macro invertebrates: Oligochaeta subclass Hirudin class, Lamelibranchiata class, Gastropoda class, Nematoda phylum, Diptera order (larvae of the families Chironomidae, Ceratopogonidae and Tipulidae), Isopoda order, Trichoptera order, Odonata order, Coleoptera order).
\end{abstract}

Keywords: Bega river, bentonic water quality, macro invertebrates.

\section{INTRODUCTION}

An important indicator of water quality in aquatic ecosystems is the structure of macrozoobenthos communities (Rosenberg \& Resh, 1993). Benthic invertebrates are sensitive indicators of ecosystem quality change, because they highlight the long-term changes in water quality, unlike assessments physical-chemical factors that highlight situations of moment (Johnson et al., 1993).

The structure and distribution of the different benthonic macro-invertebrates communities is considered to be one of the important indicators of the surface waters' quality (Badea et al., 2010; Kubosova et al., 2010; Ogbeibu \& Oribhabor, 2002).
Benthic macro invertebrates have a fundamental role in absorbing and filtering substances in aquatic ecosystems, reason for that they are good indicators of organic load, in the main, and of mineral water pollution.

Benthic invertebrates fauna is considered one constant compartment in the structure of the biocenosis water systems (Botnariuc \& Vădineanu 1982; Botnariuc et al., 1987; Ignat, 1986; Chaloner et al., 2009; Cooper et al., 2009 Wallace \& Eggert, 2009; Whiles \& Grubaugh, 2000).

The benthic macro invertebrates are good indicators of localized conditions, as many of the benthic macro invertebrates have limited migration patterns or a sessile mode of life. Most 
species have a complex life cycle of one year or more. Sensitive life stages will respond quickly to stress; the overall community will respond more slowly (Moldoveanu \& Rîşnoveanu, 2010).

The aim of this paper is to show the effects of human impact (Ghiroda village, potable water treatment station, sewage water treatment station of Timisoara, Sânmihaiu Roman village) on benthic community structure and dynamics of Bega River water.

\section{MATERIAL AND METHODS}

The samples have been collected in November 2014, when were collected 20 quantitative samples of benthic zones, in the Bega River in order to show the effects of human impact on benthic community structure and dynamics of different ecosystems from Bega River water.

Samples were collected from the upstream, middle and downstream of Timisoara city. The benthic samples were collected with Ekmansampler with a surface of $225 \mathrm{~cm}^{2}$ and were subsequently washed with benthic nets (meshes of $250 \mu \mathrm{m}$ ) and stored in $8 \%$ formaldehyde (Marin et al., 2014; Lixandru, 2006; Péterfi \& Sinitean, 2002; Petrovici, 2009).

The collecting stations (S) were located as follows (figure 1):

S1 is located upstream of Timisoara city, near Ghiroda village, upstream of potable water treatment station.
S2 is located upstream of sewage water treatment station of Timisoara.

S3 is located near Sânmihaiu Roman village from Timis County and downstream of sewage water treatment station of Timisoara.

S4 is located near Otelec village, before the border line with Serbia Country.

There have been calculated the density ( $\mathrm{Di}=$ ni / Sp), the abundance $(A=(n i / N) * 100)$ and the frequency $\left(\mathrm{F}=\mathrm{Ni}^{*} 100 / \mathrm{Np}\right)$, where ni represents the total number of individuals for the i series, $\mathrm{Sp}$ the total researched area, $\mathrm{N}$ the total number of individuals belonging to all species (from the sample or the studied samples), Ni the number of stations within which been identified the subjected species, $\mathrm{Np}$ the total number of stations (Sîrbu \& Benedek, 2004; Stan, 1995).

\section{RESULTS AND DISCUSSION}

After the laboratory work was carried out, it was identified ten groups of benthic macroinvertebrates (table 1): Oligochaeta subclass Hirudin class, Lamelibranchiata class, Gastropoda class, Nematoda phylum, Diptera order (larvae of the families Chironomidae, Ceratopogonidae and Tipulidae), Isopoda order, Trichoptera order, Odonata order, Coleoptera order and macro invertebrates density is presented in figure 2 .

The high tolerance to the impurification of Oligochaeta subclass and Chironomidae order has been demonstrated in numerous studies

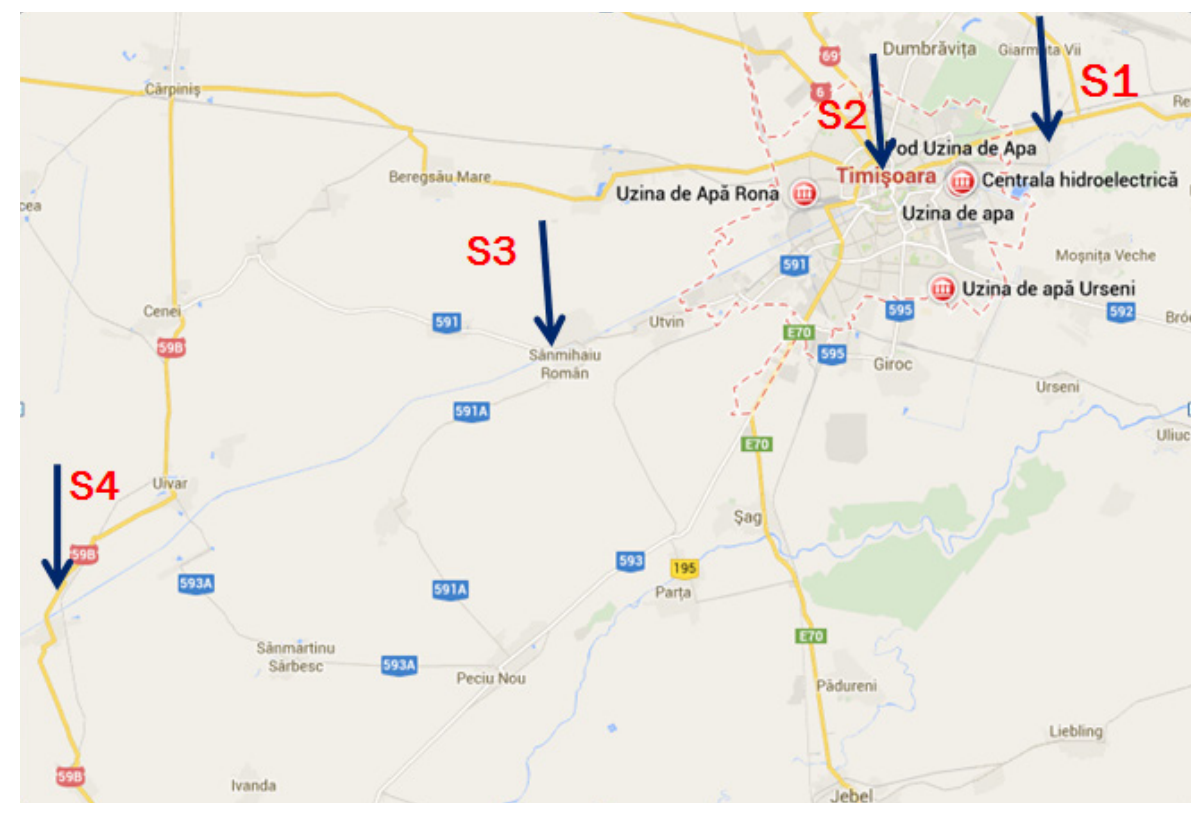

Fig. 1. The location of the sample collecting stations on Bega River water 
(Benbow, 2009; Collier et al., 2010; Courtney \& Merritt, 2009; Marchese et al., 2008). These two groups of invertebrates show significantly larger tolerance limits, adapting to various environmental conditions (Lucan-Bouché et al., 1999; Verdonschet, 1999).

At the first station (S1) have been identified groups which Lorenz (2003) considered that they are indicators of unpolluted water (Lamelibranchiata class, Gastropoda class, Odonata order).

Analyzing the macro invertebrates density (fig. 2 ), we can say that at the first stations the density of individual's that belong to the Oligochaeta subclass and Chironomidae order have a density which is smaller than the density of individual's that belong to the Gastropoda class which means that the degree of impurification of this station is very small.

Analyzing the macro invertebrates density at the second station (fig. 2) we can notice an increase of the density values of groups which are classified as indicators of unpolluted water (Lamelibranchiata class, Gastropoda class). At this station we can notice the highest density values of sensitive groups to the pollution

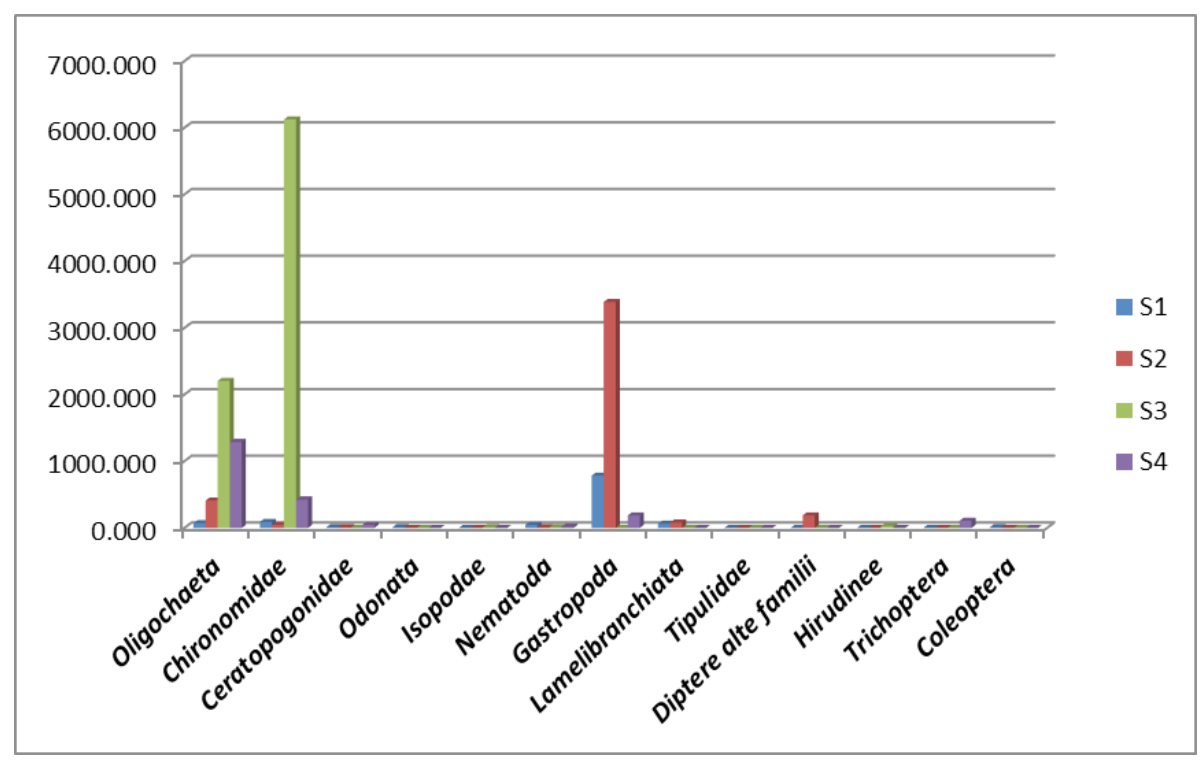

Fig. 2. Macro invertebrate's density (individual's $\mathrm{m}^{2}$ ) from Bega River

Tab. 1. Groups of saprobionți in relation whith the collection stations

\begin{tabular}{|c|c|c|c|c|}
\hline Groups & Station $1(\mathrm{~S} 1)$ & Station 2 (S2) & Station 3 (S3) & Station 4 (S4) \\
\hline Oligochaeta & $\mathrm{x}$ & $\mathrm{x}$ & $\mathrm{x}$ & $\mathrm{x}$ \\
\hline Hirudinea & & & $\mathrm{x}$ & \\
\hline Lamelibranchiata & $\mathrm{x}$ & $\mathrm{x}$ & & \\
\hline Gastropoda & $\mathrm{x}$ & $\mathrm{x}$ & & $\mathrm{x}$ \\
\hline Nematoda & $\mathrm{x}$ & $\mathrm{x}$ & & $\mathrm{x}$ \\
\hline Chironomidae & $\mathrm{x}$ & $\mathrm{x}$ & $\mathrm{x}$ & $\mathrm{x}$ \\
\hline Ceratopogonidae & $\mathrm{x}$ & $\mathrm{x}$ & & $\mathrm{x}$ \\
\hline Tipulidae & & & $\mathrm{x}$ & $\mathrm{x}$ \\
\hline Isopodae & & & $\mathrm{x}$ & \\
\hline Trichoptera & & & & $\mathrm{x}$ \\
\hline Odonata & $\mathrm{x}$ & & & \\
\hline Coleoptera & $\mathrm{x}$ & & & \\
\hline
\end{tabular}


At the station three (S3) we can observe that the values of density for sensitive groups to the pollution (Lamelibranchiata class, Gastropoda class) start to decline and increase the density values of groups show significantly larger tolerance limits of pollution (Oligochaeta subclass and Chironomidae order).

At this station we can notice the highest density values to the groups who have a high tolerance to the pollution.

Also at S3 are identified individual's that belong to the Hirudin class and Isopoda order, groups who show significantly larger tolerance limits at impurification and the disappear the individual's that belong to the Lamelibranchiata class, Gastropoda class, Odonata order.

The last station (S4) it is located near Otelec village, before the border line with Serbia Country. At this station decrease the density values of individual's that belong to the Oligochaeta subclass and Chironomidae order and appear the individual's that belong to the Gastropoda class. Also at this station are identified individual's than belong to the Trichoptera order, macro invertebrates who are considered indicators of the indicators of unpolluted water (Lorenz, 2003).

Regarding to the numerical abundance we can notice that is in correlation with the density, if the values of density grow up, then the numerical abundance shows increased values (fig. 3 ).
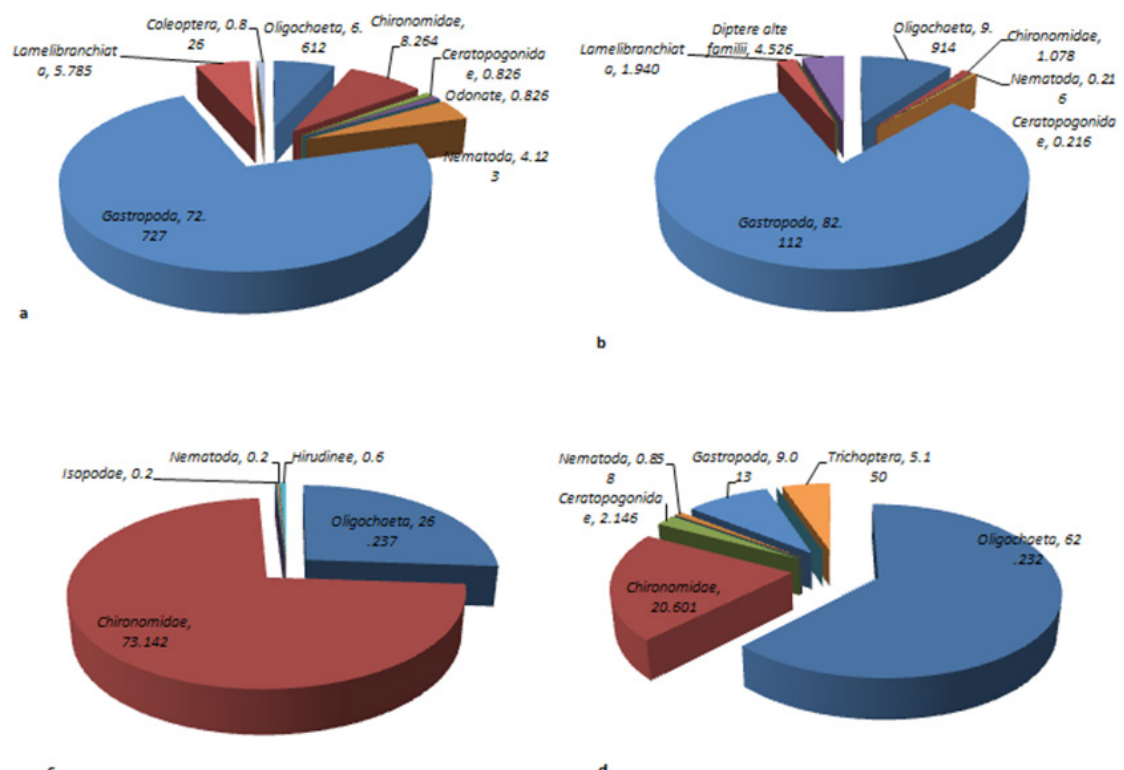

Fig. 3. The numerical abundance of the invertebrates group at: a- first station, b- station 2, c- station 3 , d- station 4. 


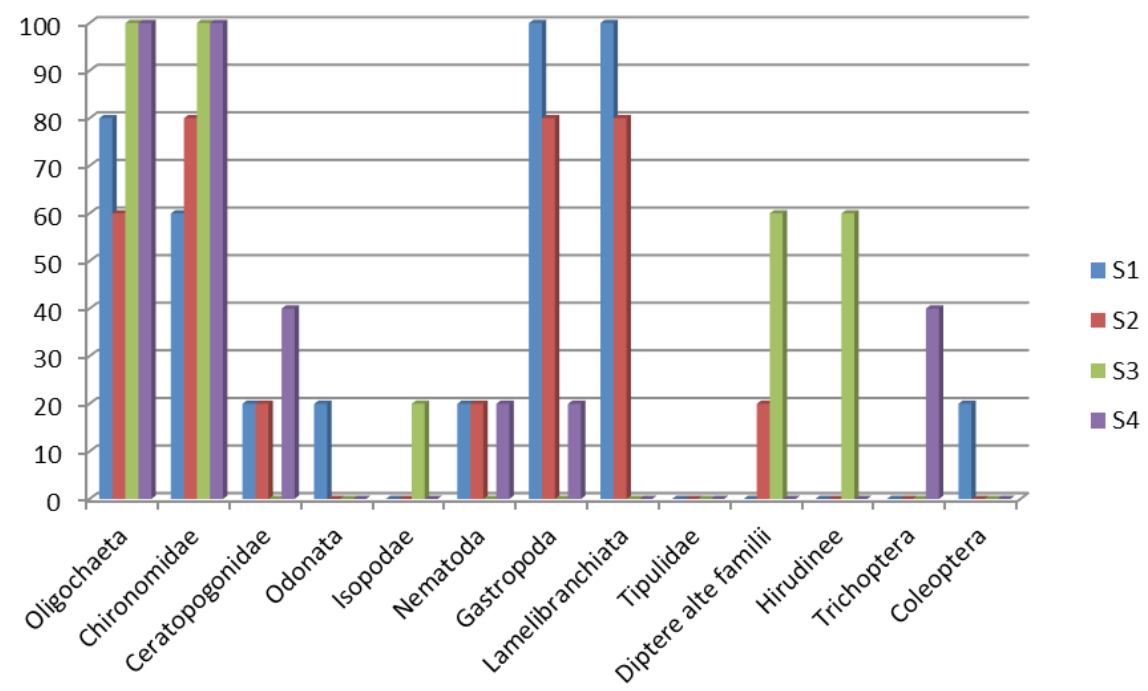

Fig. 4. Macro invertebrate's frequency in the Bega River (\%)

\section{CONCLUSIONS}

Have been identified ten groups of benthic macro invertebrates: Oligochaeta subclass Hirudin class, Lamelibranchiata class, Gastropoda class, Nematoda phylum, Diptera order (larvae of the families Chironomidae, Ceratopogonidae and Tipulidae), Isopoda order, Trichoptera order, Odonata order, Coleoptera order.

In conclusions we can say:

at the first and the second station has been identified groups who are considered indicators of unpolluted water (Lamelibranchiata class, Gastropoda class, Odonata order), and at the three station this groups disappear,

at the second station was notice the highest density values to the groups who are indicators of unpolluted water and to the three station was notice the highest density values to the groups who have a high tolerance to the pollution (Oligochaeta subclass, Diptera order),

at the last station decrease the density values of the groups who have a high tolerance to the pollution and appear macro invertebrates who are considered indicators of the indicators of unpolluted water.

Acknowledgments. On this way I want to thank my scientific mentor and all my collaborators for their support in achieving these experiments.

\section{REFERENCES}

1. Badea, B. A., Gagyi-Palffy, A., Stoian, L. C., Stan, G., (2010) Preliminary studies of quality assessment of aquatic environments from Cluj suburban areas, based on some invertebrates bioindicators and chemical indicators. AACL Bioflux 3(1):35-41.

2. Benbow, M. E., (2009). Annelida, Oligochaeta and Polychaeta. Encyclopedia of Inland Waters 55:124-127.

3. Botnariuc, N., Vădineanu, A. (1982). Ecologie. Editura Didactică și Pedagogică, București.

4. Botnariuc, N., Ignat, Gh., Diaconu, I., Vadineanu, A. (1987), L'évolution de l'état trophique des ecosystèmes aquatiques caractéristiques au Delta du Danube: 5. La structure et la dynamique de la faune benthonique, Rev. Roum. Biol. Anim. 32 (2): 121-127.

5. Chaloner, D.T., Hershey, A.E., Lamberti, G.A. (2009), Benthic Invertebrate Fauna. In: Editor-in-Chief: Gene E. Likens, Editor(s)-in-Chief, Encyclopedia of Inland Waters, Academic Press, Oxford, pp. 157-172.

6. Collier, K. J., Winterbourn, M. J., Jackson, R. J. (2010). Impacts of wetland afforestation on the distribution of benthic invertebrates in acid streams of Westland, New Zealand. New Zealand Journal of Marine and Freshwater Research 23:479-490.

7. Cooper Z.N., McGuire A., Jones S., Le Grand J. (2009) Equity, waiting times, and NHS reforms: retrospective study. BMJ 339: b3264 doi10.1136/bmj/b3264.

8. Courtney, G. W., Merritt, R. W. (2009). Diptera (Non-Biting Flies). Encyclopedia of Inland Waters 55:288-298.

9. Ignat, G. (1986). Ecologia unor populatii de chironomide din apele Deltei Dunarii. PhD thesis. University of Bucharest.

10. Johnson, M. K., Hashtroudi, S., \& Lindsay, D. S. (1993). Sourcemonitoring. Psychological Bulletin, 114, 3-28.

11. Kubosova, K., Brabec, K., Jarkovsky, J., Syrovatka, V. (2010). Selection of indicative taxa for river habitats: a case study on benthic macroinvertebrates using indicator species analysis and the random forest methods. Hydrobiologia 651:101-114.

12. Lixandru, B. (2006). Metodologie ecologică. Editura Eurobit, Timişoara. 
13. Lorenz, C. M. (2003). Bioindicators for ecosystem management, with special reference to freshwater systems. Trace Metals and other Contaminants in the Environment 6:123-152.

14. Lucan-Bouché, M. L., Risbourg, S. B., Arsac, F., Vernet, G. (1999). An original decontamination process developed by the aquatic oligochaete Tubifex tubifex exposed to copper and lead. Aquatic Toxicology 45:19-17.

15. Marchese, M. R., Rodriguez, A. R., Pave, P. J., Carignano, M. R.(2008). Benthic invertebrates structure in wetlands of a tributary of the middle Parana River (Argentina) affected by hydrologic and anthropogenic disturbances. Journal of Environmental Biology 29(3): 343-348

16. Marin, Anca-Andreea, Lixandru, B., Petrovici, Milca, Sinitean A., Morariu Florica, Popescu D. (2014). Research regarding the diversity of the saprobionte categories in Bega river waters, Book of abstracts, No 1/ 2014, USAMV Cluj -Napoca,

17. Moldoveanu, M., Rîşnoveanu, G. (2010). Achievements and limitations for monitoring and assessing ecological integrity of lotic systems, National Conference NIHWM, 28-30 September, Bucharest, Cd version: 236-244.

18. Ogbeibu, A. E., Oribhabor, B. J. (2002). Ecological impact of river impoundment using benthic macro-invertebrates as indicators. Water Research 36:2427-2436.

19. Sîrbu, I., Benedek, A.,M., (2004). Practical Ecology, Editura Universității Lucian Blaga, pp. 28-254, Sibiu,
20. Péterfi, L.Șt. \& Sinitean, A. (2002). Preliminary Studies on Diatoms in Thermo mineral Springs from Băile Herculane (Caraş - Severin District), Studies of Biodiversity, West Romania Protected Areas, USAMVBT, 25-28.

21. Petrovici, Milca, (2009). Evaluarea calității apei râului Crișul Repede utilizând larvele de efemeroptere (Insecta: Ephemeroptera) ca bioindicatori), Editura Universității din Oradea

22. Rosenberg, D. M. and V. H. Resh. (1993). Introduction to freshwaterbiomonitoringand benthic macroinvertebrates. In: D.M. Rosenberg and V.H. Resh, eds. Freshwater Biomonitoring and Benthic Macroinvertebrates. Chapman and Hall, New York.

23. Stan, G., (1995).Statistical methods with applications in entomological research (VII)]. Bul Inf Soc Lepid Rom 6:67-96. [In Romanian]

24. Verdonschet, P. F. M. (1999). Microdistribution of oligochaetes in a soft-bottomed lowland stream. Hydrobiologia 139:149-163.

25. Wallace, J.B \& Eggert, S.L. (2009). Benthic Invertebrate Fauna, Small Streams. In: Editor-in-Chief: Gene E. Likens, Editor(s)-in-Chief, Encyclopedia of Inland Waters, Academic Press, Oxford, pp. 173-190.

26. Whiles, M.R., Grubaugh, J.W., (2009). Benthic Invertebrate Fauna, River and Floodplain Ecosystems. In: Editor-inChief: Gene E. Likens, Editor(s)-in-Chief, Encyclopedia of Inland Waters, Academic Press, Oxford, pp. 205-215 